\title{
DERMATOPHYTOSIS: ASSOCIATION BETWEEN ABO BLOOD GROUPS AND REACTIVITY TO THE TRICHOPHYTIN
}

Fátima Regina VILANI-MORENO(1), Maria Sueli Parreira de ARRUDA(2), Simone Guadgnucci CLARO(1), Elaine Valim Camarinha MARCOS(1) \& Somei URA(3)

\begin{abstract}
SUMMARY
The authors investigated the relationship between dermatophytosis and ABO blood groups through blood typing, identification of isolated dermatophytes and specific cellular immune response of 40 individuals carriers of this mycosis. They verified that the fungus Trichophyton rubrum, isolated from $54.5 \%$ of the patients, was more frequent in individuals belonging to blood group A. The cellular immune response, evaluated through the trichophytin antigen, was positive in $25 \%$ of the studied patients; the presence of immediate reactions (30 minutes) was verified in 35\%. The blood group distribution among patients with dermatophytosis and control groups was, respectively: $47.5 \%$ X $36 \%$ in group A, $40 \%$ X 50\% in group O, $12.5 \%$ X $11 \%$ in group B. Even though the authors have found a higher number of patients belonging to blood group A infected by T. rubrum, these results suggest that there is no statistical evidence that these individuals are more susceptible to dermatophytosis.
\end{abstract}

KEYWORDS: Dermatophytosis; Blood groups; Dermatophyte; Trichophytin.

\section{INTRODUCTION}

Dermatophytosis are infections caused by fungi that colonize the keratin of nails, hair and skin ${ }^{1}$. Three genders of fungi comprehend the dermatophytes: Trychophyton, Microsporum and Epidermophyton with morphological, physiological and antigenic characteristics that relate them to each other ${ }^{1}$.

Studies involving cell wall of dermatophytes have demonstrated that the fungi Trychophyton mentagrophytes, T. rubrum and Epidermophyton floccosum have glycoproteins that are antigenically similar to human erythrocyte isoantigen $\mathrm{A}^{20}$. According to the authors, individuals that have these erythrocytic antigens would be more susceptible to development of generalized dermatophytosis and resistant to the treatment than the individuals devoided of these antigens.

Upon investigation of this premise, BALAJEE et $a .^{2}$ found high incidence of dermatophytosis carrier individuals belonging to blood group A, and from those, $89.8 \%$ presented chronic dermatophytosis with persistent lesions for more than five years. Similarly, GAMBORGNIELSEN $^{7}$ verified higher incidence of individuals belonging to this blood group and infected by the fungus T. mentagrophytes. Contrary to this data, NEERING ${ }^{14}$ couldn't demonstrate any relationship between blood group and dermatophyte infection.

In the face of these results and considering the lack of studies about the subject, the aim of the present work was to investigate this possible relationship through the identification of the dermatophyte isolated, blood group and specific cellular immune response in dermatophytosis patients.

\section{PATIENTS AND METHOD}

Forty patients with dermatophytosis diagnosed through clinical signs and laboratory tests participated of this study. Samples of scales of the skin and nails were collected and submitted to direct mycological examination, according to conventional methods. Material collected from 34 patients was cultured in "Mycobiotic" (Difco Lab., Detroit, Michigan, USA) medium kept at $25^{\circ} \mathrm{C}$ and colony growth was observed for 3 weeks. After that, it was done a microculture and based on the results, the dermatophyte was identified.

Blood group determination was realized in tubes, according to manufacturer's recommendation. In summary, heparinized blood sample was washed with $0.85 \%$ saline (SS) and prepared to a final concentration of 5\% in SS; a drop of this solution was mixed respectively with a antiA, anti-B, anti-AB and Anti-D (Biotest, São Paulo, Brazil) serum drops. The samples considered positive were the ones that presented agglutination. The individuals whose samples didn't react with the tested antibodies were considered as belonging to blood group $\mathrm{O}$.

The Laboratório de Imunogenética do Hospital de Reabilitação de Anomalias Crâniofaciais da Universidade de São Paulo, Bauru, supplied the data about blood group distribution in the healthy population of the region of Bauru (control group). They were obtained from 723 Caucasoid

(1) Equipe Técnica de Imunologia, Instituto "Lauro de Souza Lima", Bauru, SP, Brasil.

(2) Departamento de Ciências Biológicas, Faculdade de Ciências, UNESP/Bauru, SP, Brasil.

(3) Equipe Técnica de Clínica e Terapêutica, Instituto "Lauro de Souza Lima", Bauru, SP, Brasil.

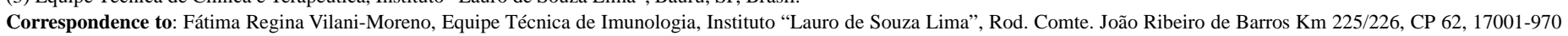
Bauru, SP, Brasil. Fax: 014-2304747, Tel: 014-2302244. E-mail: Imunologia@ ilsl.br 
individuals listed for organ donation, paternity tests and anthropological studies.

The development of specific cellular immunity was investigated through intradermal test with the trichophytin antigen (Alerbrás, Rio de Janeiro, Brazil). The reaction was observed after 30 minutes and 48 hours. It was considered as positivity parameter: a) immediate reaction (30 minutes) - irradiated erithema resembling the rays of a wheel $\left.{ }^{4} ; b\right)$ delayed reaction (48 hours) - induration with diameter equal or superior to $5.0 \mathrm{~mm}^{4}$.

In order to verify if there was higher susceptibility to dermatophytosis in different blood groups, the results were submitted to statistical analysis. The Qui-square $\left(\chi^{2}\right)$ test was applied to compare observed and expected frequencies.

\section{RESULTS}

From the samples of the 34 patients submitted to culture, 22 were positive. The fungus T. rubrum was isolated from $54.5 \%$ of the patients, while T. mentagrophytes from $32 \%$. The association between the isolated dermatophytes and the clinical forms observed is represented in Table 1.

The blood group distribution in dermatophytosis patients demonstrated that $47.5 \%$ of the patients belonged to group A, $40 \%$ to group $\mathrm{O}$ and $12.5 \%$ to group $\mathrm{B}$. In the control samples the blood groups are distributed as follow: $50 \%$ group O, $36 \%$ group A, $11 \%$ group B and $3 \%$ group $\mathrm{AB}$. The statistical analysis, using Qui-square test, indicated that there isn't any significant difference between the expected and observed frequencies $\left(\chi^{2}=2.233 \mathrm{p}>0.30\right)$.

The relationship between blood group and isolated dermatophyte is represented in Table 2 . The fungus T. rubrum was found in $50 \%$ of the patients belonging to blood group A, 33.5\% belonging to blood group $\mathrm{O}$ and $16.5 \%$ to group B; T. mentagrophytes was isolated from $57 \%$ of the patients belonging to group $\mathrm{O}$ and $43 \%$ to group $\mathrm{A}$.

Of the 40 studied patients, $25 \%$ were reactors to the delayed phase of the trichophytin reaction and $35 \%$ to the immediate phase. The association between immediate and delayed reaction has shown that

Table 1

Distribution of clinical forms according to isolated dermatophyte

\begin{tabular}{lcccc}
\hline Clinical forms of & \multicolumn{4}{c}{ Species of isolated dermatophyte } \\
dermatophytosis & T. rubrum & T. mentagrophytes & T. sp & M. canis \\
\hline Tinea pedis & 02 & 01 & - & - \\
Tinea corporis & 01 & 02 & 02 & 01 \\
Tinea cruris & 04 & - & - & - \\
Tinea unguium & 02 & - & - & - \\
Tinea pedis/unguium & 01 & - & - & - \\
Tinea pedis/corporis & - & 01 & - & - \\
Tinea pedis/cruris & - & 01 & - & - \\
Tinea corporis/cruris & 02 & 01 & - & - \\
Tinea corporis/unguium & - & 01 & - & - \\
\hline Total & 12 & 07 & 02 & 01 \\
\hline
\end{tabular}

Table 2

Blood group result frequency according to species of isolated dermatophytes

\begin{tabular}{lcccccccc}
\hline \multirow{2}{*}{ Blood } & \multicolumn{9}{c}{ Species of isolated dermatophytes } \\
Group & T.rubrum & T.mentagrophytes & Trychophyton sp & \multicolumn{2}{c}{ M. canis } \\
& $\mathrm{n}$ & $\%$ & $\mathrm{n}$ & $\%$ & $\mathrm{n}$ & $\%$ & $\mathrm{n}$ & $\%$ \\
\hline A & 6 & 54.5 & 3 & 27.5 & 1 & 9.0 & 1 & 9.0 \\
O & 4 & 44.5 & 4 & 44.5 & 1 & 11.0 & 0 & 0.0 \\
B & 2 & 100.0 & 0 & 0.0 & 0 & 0.0 & 0 & 0.0 \\
\hline Total & 12 & & 7 & & 2 & & 1 & \\
\hline
\end{tabular}


Table 3

Trichophytin test result frequency observed in patients carriers of dermatophytes according to isolated species

\begin{tabular}{|c|c|c|c|c|c|c|c|c|c|}
\hline \multirow[t]{3}{*}{$\begin{array}{l}\text { Isolated } \\
\text { dermatophyte }\end{array}$} & \multirow{3}{*}{$\begin{array}{c}\text { Total of } \\
\text { samples } \\
n\end{array}$} & \multicolumn{4}{|c|}{$\begin{array}{l}\text { Immediate reaction } \\
\text { to trichophytin }\end{array}$} & \multicolumn{4}{|c|}{$\begin{array}{l}\text { Delayed reaction } \\
\text { to trichophytin }\end{array}$} \\
\hline & & & & & & & & & \\
\hline & & $\mathrm{n}$ & $\%$ & $\mathrm{n}$ & $\%$ & $\mathrm{n}$ & $\%$ & $\mathrm{n}$ & $\%$ \\
\hline T. rubrum & 12 & 6 & 50 & 6 & 50 & 2 & 17 & 10 & 83 \\
\hline T.mentagrophytes & 7 & 3 & 43 & 4 & 57 & 3 & 57 & 4 & 43 \\
\hline Trychophyton sp & 2 & 1 & 50 & 1 & 50 & 1 & 50 & 1 & 50 \\
\hline M. canis & 1 & 0 & 0 & 1 & 100 & 0 & 0 & 1 & 100 \\
\hline Total & 22 & 10 & & 12 & & 6 & & 16 & \\
\hline
\end{tabular}

Table 4

Blood group distribution according to immediate and delayed phases response to the trichophytin antigen

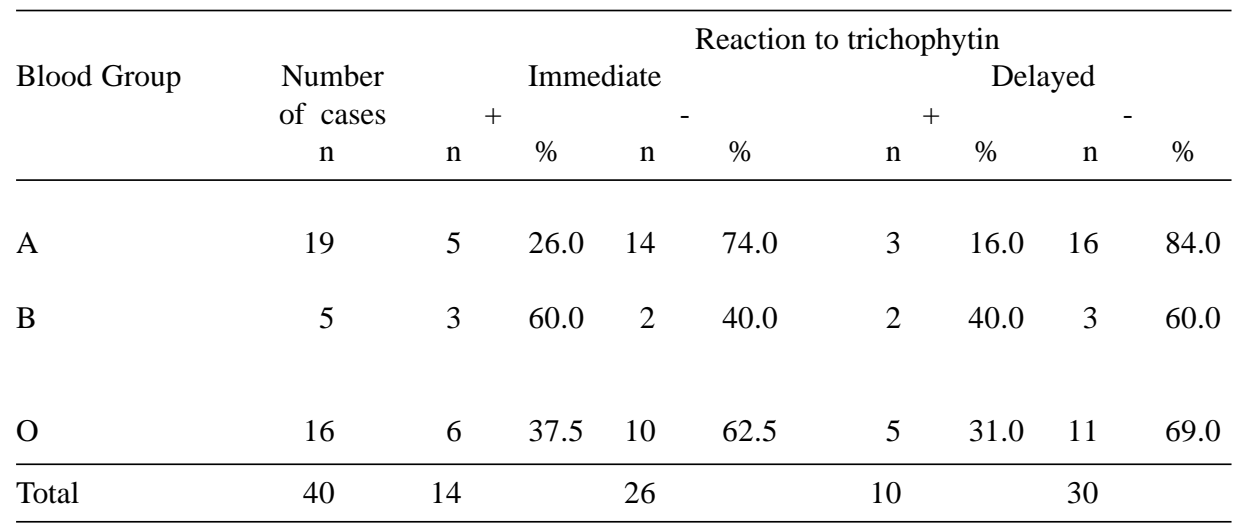

although most of the patients with positive immediate reaction were negative to the delayed reaction, $29 \%$ of them exhibited positivity to the two phases of the reaction.

The association between the response to trichophytin, isolated dermatophyte and blood group revealed positivity to the immediate reaction in $50 \%$ of the patients infected by $T$. rubrum and $43 \%$ by $T$. mentagrophytes (Table 3 ). The reactivity to the delayed phase was observed in $40 \%$ of the patients of the blood group B, $31 \%$ of group $\mathrm{O}$ and $16 \%$ of group A (Table 4).

\section{DISCUSSION}

Several researchers have studied the relationship between blood group and infectious diseases. In Hansen' s disease, BEIGUELMAN ${ }^{3}$ verified that the frequency of individuals of blood group $\mathrm{O}$ was higher in patients with the tuberculoid clinical form when compared to the lepromatous form. In coccidioidomycosis, DERESINSKI et al. ${ }^{5}$ observed higher prevalence of the disease in individuals from group B. In the same way, there are studies suggesting that individuals belonging to this blood group present Gram negative bacterial infections with higher frequency than individuals belonging to the remaining blood groups ${ }^{6,15,16}$. Besides, VOGEL et al. ${ }^{19}$ suggested that mortality due to smallpox is higher in individual from group A and AB. In dermatophytosis, YOUNG \& $\mathrm{ROTH}^{20}$ observing antigenic similarities between $T$. rubrum, T. mentagrophytes and E. floccosum cell wall glycoproteins and A1 and A2 human erythrocyte isoantigens, suggested that a possible cross reactivity would turn individual belonging to blood group A more susceptible to chronic dermatophyte infections.

Even though in the present work we have verified that $47.5 \%$ of the patients carriers of dermatophytes and $36 \%$ of the control group belonged to group A, the statistical analysis of the results didn't show any significant difference between patients and control group. This suggests that there isn't higher susceptibility of individual from group A to dermatophyte infections. Our study supports the findings of NEERING ${ }^{14}$ that reported not having found evidences of higher susceptibility of individuals from blood group A to dermatophytosis. 


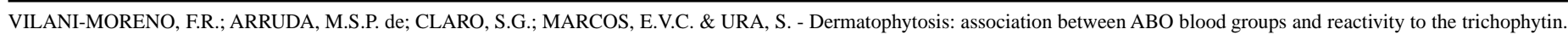
Rev. Inst. Med. trop. S. Paulo, 41 (5): 285-289, 1999.

GAMBORG-NIELSEN ${ }^{7}$ while evaluating patients with hereditary palmoplantar keratoderma and dermatophytosis found higher frequency of individuals from group A and infected by T. mentagrophytes. Similarly, BALAJEE et $a l .^{2}$ suggested that individual from group A are more susceptible to dermatophyte fungi infections once they found an increased percentage of patients belonging to this blood group when compared to the control group $(45.4 \% \times 18 \%)$.

In our study, the dermatophyte infections were frequently caused by T. rubrum (54.5\%) and T. mentagrophytes (32\%), being the most common clinical form the Tinea corporis. The association between isolated dermatophyte and blood group revealed that T. rubrum was found in $50 \%$ of the patients from group A, while T. mentagrophytes in $43 \%$. This result differs of the found by GAMBORG-NIELSEN ${ }^{7}$ that verified higher frequency of T. mentagrophytes in patients from blood group A.

The development of specific cellular immune response to dermatophytes was evaluated by the trichophytin test ${ }^{18}$. The frequency of positivity in the delayed type hypersensitivity reaction in dermatophytosis varies from author to author. It has been suggested that such discrepancies could be due to the disease evolution time, nature and localization of the lesions, or still, to the species of dermatophyte involved $^{8,13,18}$. In this study we obtained positive reactions in patients infected by T. rubrum and T. mentagrophytes, although we have observed higher percentage in the cases where this latter was isolated.

The infection by T. rubrum has frequently been associated to the presence of immediate reaction to the trichophytin ${ }^{11}$. In the present study, immediate reactions were verified in patients with T. rubrum $(55.5 \%)$ and also in patients with T. mentagrophytes (33\%). These results are similar to the found by GAMBORG-NIELSEN ${ }^{7}$ and VILANI-MORENO $\&$ ARRUDA $^{17}$, and they suggest that albeit the immediate reaction is more frequent in patients infected by $T$. rubrum, this can be shown in patients infected by other dermatophytes.

Several authors have demonstrated that most of the individuals who develop immediate reaction don't manifest delayed reaction ${ }^{9,10,11,12}$. In the case that both happen, the delayed reactions are of lower intensity ${ }^{11}$. It has been suggested that these results would be related to the presence of IgE that could deplete fungal antigens available by binding to them, or form complexes that would affect non-specifically the delayed hypersensitivity reaction ${ }^{11}$.

In our study we verified that $71.5 \%$ of the patients who manifested positive immediate reaction didn't develop delayed reaction confirming the results found in the literature ${ }^{9,11,12,17}$. The manifestation of the two reactions was verified in $28.5 \%$ of the patients, which suggests that mechanisms other than the immediate reaction could be involved in the non-response in the delayed phase to the trichophytin reaction.

The evaluation of the specific immune response in patients belonging to blood group A showed that $26 \%$ were reactors in the immediate phase of the reaction and $16 \%$ in the delayed phase. In the reviewed literature, we didn't find an association between the results of the trichophytin test and blood group. However, the reactivity to the test can be explained by the fact that the trichophytin antigen to be an extract obtained from several dermatophyte cultures, so that, even the individual from blood group A having antigenic determinants in his erythrocytes, similar to the ones found in the cell wall of the T. mentagrophytes, T. rubrum and E. floccosum dermatophytes ${ }^{20}$, he is able to react with the remaining antigenic determinants of dermatophytes.

The results obtained in our study suggest that, although we have found a larger number of patients belonging to blood group A and infected by $T$. rubrum, there is no statistical evidence that those individuals are more susceptible to dermatophytosis.

\section{RESUMO}

\section{Dermatofitose: associação entre grupos sanguíneos ABO e reatividade à tricofitina}

Os autores investigaram a relação entre dermatofitose e grupo sanguíneo ABO através da tipagem sanguínea, identificação do dermatófito isolado e resposta imune celular específica de 40 indivíduos portadores desta micose. Verificaram que o fungo Trichophyton rubrum foi isolado em $54,5 \%$ dos pacientes, sendo mais frequente em indivíduos pertencentes ao grupo sanguíneo A. A resposta imune celular, avaliada através do antígeno tricofitina, foi positiva em $25 \%$ dos pacientes estudados; a presença de reações imediatas (30 min) foi verificada em $35 \%$. A distribuição dos grupos sanguíneos entre pacientes com dermatofitose e grupo controle foi a seguinte: $47,5 \%$ × $36 \%$ grupo A, $40 \%$ x $50 \%$ grupo O, $12,5 \%$ x $11 \%$ grupo B. Embora os autores tenham encontrado um número maior de pacientes pertencentes ao grupo sanguíneo A e infectados pelo T. rubrum, não obtiveram evidência estatística de que esses indivíduos sejam mais suscetíveis às dermatofitoses.

\section{ACKNOWLEDGMENTS}

To the biologist Heloísa Helena Escudeiro for accomplishing the mycology tests; to Dr. Elza Araújo Torres, Chief of the Laboratório de Imunogenética do Hospital de Reabilitação de Anomalias Crâniofaciais da USP, Bauru, for providing the blood groups of the healthy population that constituted the control group of this work, and to Dr. Henrique Salgado, of the Departamento de Engenharia de Produção da Faculdade de Engenharia da UNESP, Bauru, for doing the statistical analysis of the results.

\section{REFERENCES}

1. AZULAY, R.D. - Micoses superficiais. Rev. bras. Clin. Terap., 14: 154-158, 1985.

2. BALAJEE, S.A.M.; MENON, T. \& RANGANATHAN, S. - ABO blood groups in relation to the infection rate of dermatophytosis. Mycoses, 39: 475-478, 1996.

3. BEIGUELMAN, B. - Grupos sanguíneos e Lepra. Rev. bras. Leprol., 31: 34-44, 1963.

4. DAHL, M.V. - Host defense: fungus. In: Clinical immunodermatology. Chicago, Year Book Medical, 1981. p.127.

5. DERESINSKI, S.C.; PAPPAGIANIS, D. \& STEVENS, D.A. - Association of ABO blood group and outcome of coccidioidal infection. Sabouraudia, 17: 261-264, 1979.

6. FOSTER JR., M.T. \& LOBRUM, A.H. - Relation of infection with Neisseria gonorrhoea to ABO blood groups. J. infect. Dis., 133: 329-330, 1976. 

Rev. Inst. Med. trop. S. Paulo, 41 (5): 285-289, 1999.

7. GAMBORG-NIELSEN, P. - Hereditary palmoplantar keratoderma and dermatophytosis in the Northernmost Country of Sweden. Goteborg, 1994. (Thesis - Department of Dermatology/Goteborg University).

8. HAY, R.J. \& SHENNAN, G. - Chronic dermatophyte infection. II. Antibody and cellmediated immune responses. Brit. J. Derm., 106: 191-198, 1982.

9. HELANDER, I. - Leukocyte migration agarose test in dermatophytosis. Mykosen, 21: $167-175,1978$.

10. JONES, H.E.; REINHARDT, J.H. \& RINALDI, M.G. - A clinical, mycological and immunological survey for dermatophytosis. Arch. Derm., 108: 61-65, 1973.

11. JONES, H.E.; REINHARDT, J.H. \& RINALDI, M.G. - Immunologic susceptibility to chronic dermatophytosis. Arch. Derm., 110: 213-220, 1974.

12. KAAMAN, T. - The clinical significance of cutaneous reactions to Trichophyton in dermatomycosis. Acta derm.-venereol. (Stockh.), 58: 139-143, 1978.

13. LEWIS, G.M. - Trichophytin test: its value as diagnostic aid. Arch. Derm. Syph. (Chic.), 38: $713-726,1938$

14. NEERING, H. - Chronic Trichophyton rubrum infections and blood group. J. invest. Derm., 73: 392, 1979.
15. ROBINSON, M.G.; TONCHIN, D. \& HALPERN, C. - Enteric bacterial agents and ABO blood groups. Amer. J. hum. Genet., 23: 135-145, 1971.

16. SOCHA, W.B.M. \& KACZERA, Y. - Escherichia coli and ABO blood groups. Folia biol. (Praha), 17: 259-269, 1969.

17. VILANI-MORENO, F.R. \& ARRUDA, M.S.P. - Contribuição ao estudo da reação à tricofitina nas dermatofitoses. Rev. Inst. Med. trop. S. Paulo, 34: 505-509, 1992.

18. VILANOVA, X. \& CASANOVAS, M. - Les tests intradermiques à la trichophytine et à la levurine dans les mycoses cutanées et autres dermatoses. Ann. Derm. Syph. (Paris) 88: $601-612,1961$

19. VOGEL, F.; PETTENKOFER, H.J. \& HELMBOLD, W. - Über die populationsgenetik der ABO-blutgruppen. 2. Mitteilung. Genhäufigkeit und epidemische Erkrankungen. Acta genet. (Basel), 10: 267-294, 1960.

20. YOUNG, E. \& ROTH, F.J. - Immunological cross-reactivity between a glycoprotein isolated from Trichophyton mentagrophytes and human isoantigen A. J. invest. Derm., 72: 46-51, 1979.

Received: 05 April 1999

Accepted: 19 August 1999 